\title{
Long-term trends in the response of benthic macrofauna to climate variability in the Lavaca-Colorado Estuary, Texas
}

\author{
Jennifer Beseres Pollack ${ }^{1,2, *}$, Terence A. Palmer ${ }^{1}$, Paul A. Montagna ${ }^{1}$ \\ ${ }^{1}$ Harte Research Institute for Gulf of Mexico Studies, Texas A\&M University-Corpus Christi, 6300 Ocean Drive, \\ Corpus Christi, Texas 78412-5869, USA \\ ${ }^{2}$ Present address: Department of Life Sciences, Texas A\&M University-Corpus Christi, 6300 Ocean Drive, Corpus Christi, \\ Texas 78412-5800, USA
}

\begin{abstract}
Long-term trends in the response of benthic macrofauna to hydrological conditions were examined in the Lavaca-Colorado Estuary, Texas. Four stations representing a range of salinities in the Lavaca-Colorado Estuary were sampled quarterly for benthic macrofauna and hydrography from April 1988 to October 2008. The relationship between climate variability and local salinity patterns and benthic populations was investigated using the Oceanic Niño Index (ONI), North Atlantic Oscillation (NAO), and North Pacific Index (NPI). Mean salinity declined during the $20 \mathrm{yr}$ study period. Observed changes in salinity were related to river discharge and the ONI because there were more El Niño events in the first half of the study period relative to the second half. Benthic macrofaunal abundance was significantly correlated with salinity, the ONI and the NAO, indicating that global climate variability and the resulting effects on local salinity patterns are important factors shaping benthic macrofaunal communities. There was no significant linear trend in temperature over time, and negative correlations between individual taxa and temperature were likely due to seasonality. While drivers other than physical hydrological factors can obviously affect benthic macrofaunal communities, strong connections between global climate signals, precipitation, and local salinity patterns provided the most plausible mechanistic connection between climatic variability and benthic macrofaunal response in the estuary. An increasingly unstable climate may lead to potentially strong effects in estuarine ecosystems because stability is known to affect diversity and productivity. The vulnerability of estuarine ecosystems to the effects of climate variability will be exacerbated as human population growth and water resource development continues to increase the demand for and stress on coastal and marine resources.
\end{abstract}

KEY WORDS: Benthos $\cdot$ Disturbance $\cdot$ Freshwater inflow $\cdot$ Oceanic Niño Index $\cdot$ Salinity $\cdot$ Stability

\section{INTRODUCTION}

Freshwater delivery to the coast is fundamental to the function of estuaries. These highly productive semi-enclosed bodies of water receive freshwater inflow perennially or seasonally and are connected to the sea via tidal inlets that may be closed for part of the year (Wolanski 2007). The quantity, quality, and timing of freshwater inflow (and the resulting changes in salinity, nutrients, and sediments) alter the condition of estuaries, and the condition then drives the integrity, function, and sustainability of estuarine habitats (Alber 2002). The hydrologic cycle controls the dynamics of freshwater delivery to coastal ecosystems and that cycle is likely to change under a changing climate (Scavia et al. 2002). 
Climate change is predicted to cause changing patterns of precipitation and temperature in various regions of the globe. Recent attention has been given to increasing climate variability or 'global weirding' (Friedman 2010) and the resulting precipitation extremes, increases in extreme heat stress events and cooling degree days (Katz \& Brown 1992, Trenberth \& Hoar 1997, Hulme et al. 1999, Timmermann et al. 1999, Meehl et al. 2000). Within coastal ecosystems, this variability may cause more extreme salinity fluctuations, due to freshwater shortages and uncertain seasonal variability (Vörösmarty et al. 2000) caused by hurricanes (precipitation summerfall; National Hurricane Centre, National Weather Service: www.nhc.noaa.gov) and/or El Niño effects (precipitation winter-early spring; NOAA 2009).

Climate models have forecast widespread droughts in many arid and semi-arid regions of the globe, including the African Sahel and southern Africa, Central America, the Mediterranean basin, northeastern Brazil, southern Asia, eastern Australia, and western USA (Bates et al. 2008). Estuaries in these regions are susceptible to more frequent or longer-term closures of tidal inlets due to reduced freshwater flow, which may obstruct diadromous fish and crustacean migration and decimate resident communities (Schlacher \& Wooldridge 1996, Peirson et al. 2002, Whitfield et al. 2008). Resilience of macrobenthic communities to droughts in these regions can be compromised by anthropogenic activities that reduce freshwater inflow (MacKay et al. 2010). Along the Texas coast in the
USA there are significant correlations between global climate signals and local salinity patterns (Tolan 2007). Precipitation patterns are highly variable and linked to El Niño Southern Oscillation (ENSO) (Ropelewski \& Halpert 1986, Gershunov \& Barnett 1998, Tolan 2007), and the salinity structure in estuaries is driven by isolated freshwater pulses (Orlando et al. 1993). Over seasonal time scales, freshwater inflows represent the primary control on estuarine salinity gradients (Schmidt \& Luther 2002).

Understanding the link between estuarine condition and estuarine resources is the key to developing assessments of climate change effects in estuaries. This is done primarily by linking environmental condition with bioindicators. Benthic communities are uniquely qualified as bioindicators of environmental conditions because they are relatively long-lived and sessile, have an intermediate trophic position, demonstrate a variety of consistent responses to multiple sources of stress, are relatively well known (Pearson \& Rosenberg 1978, Bilyard 1987, Weisberg et al. 1997, Beseres Pollack et al. 2009), and integrate ephemeral water column conditions over time, providing a long-term record of short-term changes (Montagna et al. 2002). Benthic invertebrates are also an important food source for many commercially and recreationally important fish and crustacean species (Ellis \& Coull 1989, Mansour \& Lipcius 1991, Beseres \& Feller 2007), and thus changes in benthic community composition may affect higher trophic levels.

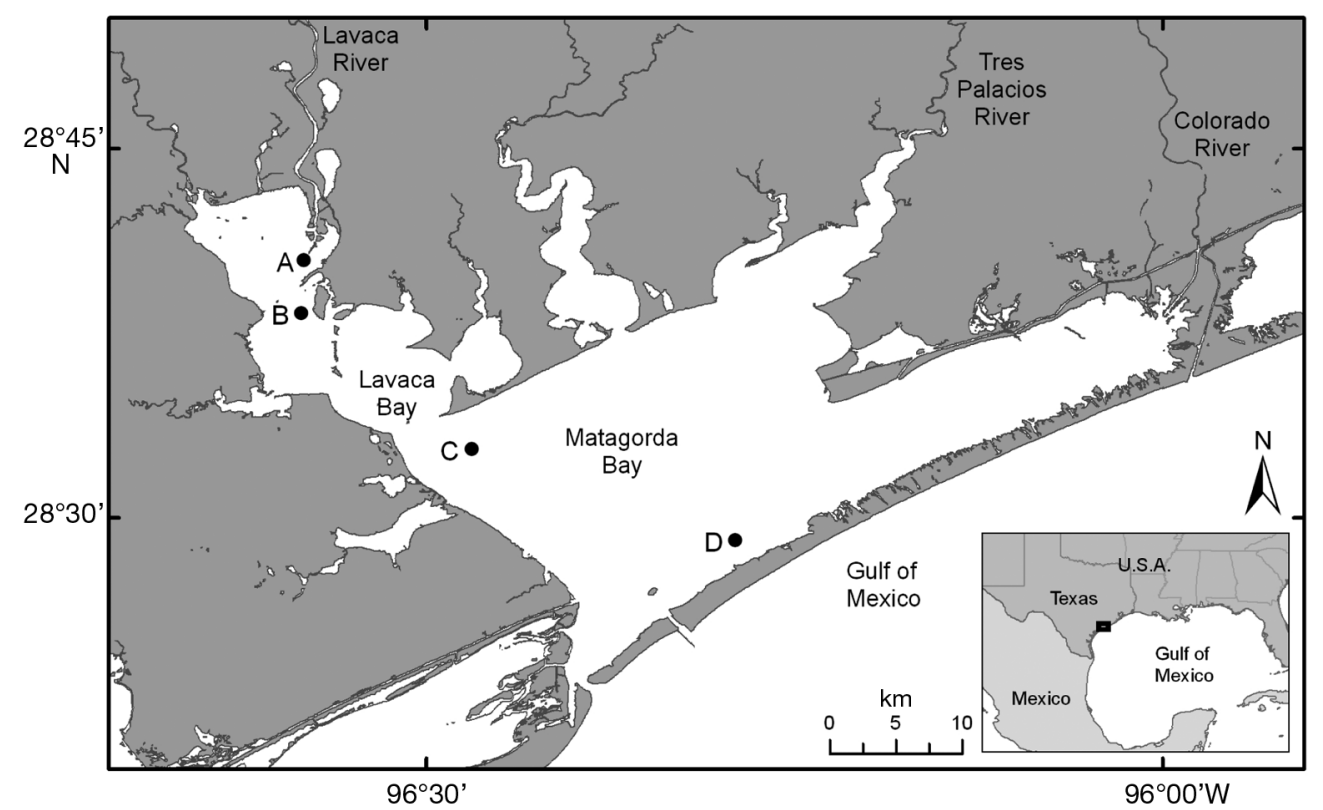

Fig. 1. Lavaca-Colorado estuary, Texas, USA, showing the locations of the sampling stations (A-D) along a salinity gradient from Lavaca Bay to Matagorda Bay 
The present study examined long-term trends and relationships between benthic macrofauna and hydrographic conditions in the Lavaca-Colorado Estuary, Texas. Understanding the response of benthic indicators to climatic variability and freshwater inflow is critical for addressing water management questions, particularly in light of increasing climate variability.

\section{MATERIALS AND METHODS}

\section{Study area}

The Lavaca-Colorado Estuary is one of 7 major estuarine systems located along the Texas coast (Fig. 1). It covers $1200 \mathrm{~km}^{2}$ and includes a primary bay, Matagorda Bay, 2 secondary bays - the largest of which is Lavaca Bay-and several smaller, tertiary bays (Orlando et al. 1993). The estuary is located in a sub-tropical humid climate with a mean annual rainfall of $107.2 \mathrm{~cm}$. The flow of freshwater into the Lavaca-Colorado Estuary has been anthropogenically altered over the last century (Montagna et al. 2008). Over 20 reservoir and dam systems have been constructed along tributaries within the LavacaColorado Estuary watershed, and the ultimate discharge point of the estuary's largest inflow source, the Colorado River, has also changed. Between 1934 and 1992, part or all of the Colorado River flow was diverted from entering the eastern arm of Matagorda Bay to flowing directly into the Gulf of Mexico (Ward \& Armstrong 1980, Wilber \& Bass 1998). The amount of inflow from the Colorado River into Matagorda Bay between the 1950s and 1990 is estimated as being negligible when river flows were small $\left(<14 \mathrm{~m}^{3}\right.$ $\mathrm{s}^{-1}$ ) and up to $80 \%$ when river flows were high (>85 $\mathrm{m}^{3} \mathrm{~s}^{-1}$ ) (Wilber \& Bass 1998 and references therein). Inflow into Matagorda Bay was increased after a diversion channel between the Colorado River and Matagorda Bay was completed in May 1990 and fully restored after the temporary Colorado River entrance to the Gulf of Mexico was dammed in 2 places in May 1991 (Tiger Island Cut dam) and July 1992 (dam across Colorado River).

The population density of the Lavaca-Colorado Estuary catchment is low, with 1.6 million people inhabiting the $110000 \mathrm{~km}^{2}$ watershed (TCRPP 2007 , Arismendez 2010). Lavaca Bay has been affected more directly by industrial development than the rest of the estuary. Elevated mercury concentrations are present in sediment on the eastern side of Lavaca Bay (Sager 2002). Anthropogenic mercury has bioac- cumulated into estuarine organisms within the contaminated zone, including oysters Crassostrea virginica, blue crabs Callinectes sapidus and finfish, although tissue concentrations have decreased slightly over time (Sager 2002) and some remediation has occurred (USEPA 2011).

Four stations representing a broad range of salinity habitats in the Lavaca-Colorado Estuary were sampled quarterly (January, April, July, October) from April 1988 to October 2008. Stns A and B were located in freshwater-dominated Lavaca Bay, and Stns C and D were located in marine-dominated Matagorda Bay (Fig. 1). Station depths were similar, ranging from 1.3 to $4.1 \mathrm{~m}$ (see Table 1). The water column was well-mixed and turbid so depth-related factors that could affect the benthos were minimal. Habitat was consistent throughout the study areas; there were no differences in sediment characteristics and no vegetated areas (Table 1, also Montagna et al. 2008). None of the stations were within the mercury contaminated zone.

\section{Sampling}

On each sampling date, hydrographic measurements were taken at the surface and bottom of the water column at each station (Table 1, Montagna et al. 2008). A multiparameter instrument (Hydrolab Surveyor II or YSI 6 series) was used to measure water temperature, dissolved oxygen and salinity. Salinity measurements were verified using a refractometer. Although not reported here, $\mathrm{pH}$, specific conductivity, water depth, wind speed, wind direction, cloud cover, and wave height were also recorded.

Bi-monthly hydrological data for Lavaca and Matagorda Bays were also obtained from the Texas Parks and Wildlife Department (TPWD) for analysis of long-term trends and relationships among macrofauna and hydrological characteristics. TPWD hydrological data from other bays within the LavacaColorado Estuary were omitted from all analyses. These data are collected throughout the estuary in association with their fisheries-independent monitoring program.

Monthly river discharge values of the Lavaca, Tres Palacios and Lower Colorado Rivers to the LavacaColorado estuary were obtained from United States Geological Survey (USGS) using upstream gages no. 08164000 (Lavaca River near Edna, TX), no. 08162600 (Tres Palacios River near Midfield, TX) and no. 08162500 (Colorado River near Bay City, TX). 
Discharge values were summed across gages to determine monthly combined riverine inflows.

Benthic macrofauna were sampled using a $6.7 \mathrm{~cm}$ diameter core tube $\left(35.4 \mathrm{~cm}^{2}\right.$ area) to a depth of $10 \mathrm{~cm}$. Three replicate cores were collected from each station on each sampling date and were preserved with $5 \%$ buffered formalin. In the laboratory, organisms were extracted on a $0.5 \mathrm{~mm}$ sieve, sorted using a stereo microscope, identified to the lowest practical identifiable level (usually species), and enumerated. Biomass measurements were obtained after combining individual macrofauna into higher taxonomic levels (Crustacea, Mollusca, Polychaeta, and others), drying at $50{ }^{\circ} \mathrm{C}$ for $24 \mathrm{~h}$, and then weighing. Mollusc shells were removed with $1 \mathrm{~N} \mathrm{HCl}$ prior to drying and weighing.

\section{Statistical analyses}

Hydrological data collected simultaneously with macrofauna sampling were used to spatially characterize the estuary (Table 1, Montagna et al. 2008). TPWD-collected hydrological variables were used in all correlations over time and with macrofaunal variables. Trends in hydrology were calculated using Spearman correlations between estuary-wide (Lavaca and Matagorda Bay) quarterly means of TPWD-collected hydrological variables and time. Although not reported, correlations were also run using both yearly and quarterly means to confirm that temporal scaling of means was not a factor in determining the significance and direction (positive or negative) of correlations.

The potential role of climate variability on local salinity patterns and benthic populations was investigated using Oceanic Niño Index (ONI), North Atlantic Oscillation (NAO) and North Pacific Index (NPI) data, which were obtained from the National Center for Atmospheric Research (NCAR, http:// ncar.edu/home). The ONI consists of 3 mo running means of sea surface temperature (SST) anomalies in the Niño 3.4 region $\left(5^{\circ} \mathrm{N}\right.$ to $5^{\circ} \mathrm{S}, 120^{\circ} \mathrm{W}$ to $\left.170^{\circ} \mathrm{W}\right)$ based on the 1971-2000 base period (see NCAR). The NAO is a prominent and recurring pattern of atmospheric circulation variability between the Arctic and subtropical Atlantic, which effects surface air temperature, winds, storminess and precipitation over the Atlantic Ocean and adjacent continents (Hurrell et al. 2003, Hurrell \& Deser 2009). NPI is the area-weighted sea level pressure over the region $30^{\circ} \mathrm{N}$ to $65^{\circ} \mathrm{N}, 160^{\circ} \mathrm{E}$ to $140^{\circ} \mathrm{W}$ (Trenberth \& Hurrell 1994). Spearman correlations were used to deter- mine the relationship of the ONI, NAO and NPI with monthly river discharge, hydrological and benthic variables. Prior to analysis, NAO was smoothed using a rolling 3 mo average (using NAO values of the previous 2 mo and current month).

Mean macrofaunal abundance, biomass and diversity for the Lavaca-Colorado Estuary were also correlated with time using Spearman correlations. Species diversity in this study was calculated using Hill's N1 diversity on pooled replicates $\left(106 \mathrm{~cm}^{2}\right)$. Hill's N1 diversity is a measure of the effective number of species and indicates the number of abundant or dominant species in a sample (Hill 1973, Ludwig \& Reynolds 1988). Although not reported in this manuscript, species richness (N0) was also correlated with time and hydrological variables. The significance and direction (positive or negative) of the correlations with species richness were the same as the correlations with Hill's N1 diversity, although the r-value varied slightly. The similarities between macrobenthic communities were analyzed using non-metric multidimensional scaling (MDS) on log-transformed $(\ln [\mathrm{x}+1])$ data (averaged by bay and quarter) using a Bray-Curtis similarity matrix. Significant groupings of communities were determined using the SIMPER routine as part of cluster analysis (Clarke 1993). Stations were grouped into bays because of the similarity between benthic communities within each bay (see Fig. 4) and because further multivariate analysis using 2nd-stage MDS (Clarke et al. 2006; results not shown here) showed that temporal variability of station communities were similar within bays but very different between bays. Correlations between hydrological variables and macrofauna community structure were determined using BIO-ENV, a multivariate procedure that calculates weighted Spearman rank correlations $\left(\rho_{\mathrm{w}}\right)$ between sample ordinations from all of the environmental variables and the ordination of species abundances for each sample (Clarke \& Ainsworth 1993). All multivariate statistics were calculated using Primer software (Clarke \& Gorley 2006).

Spearman's partial correlation coefficients were calculated to determine the strength and direction of linear relationships between single macrobenthic (abundance, biomass and diversity) and hydrological (temperature, dissolved oxygen and salinity) variables. The partial correlations measure the degree of association between the macrobenthic and hydrological variables while statistically controlling for the potential effects of other hydrological variables in the model. A partial lag was incor- 

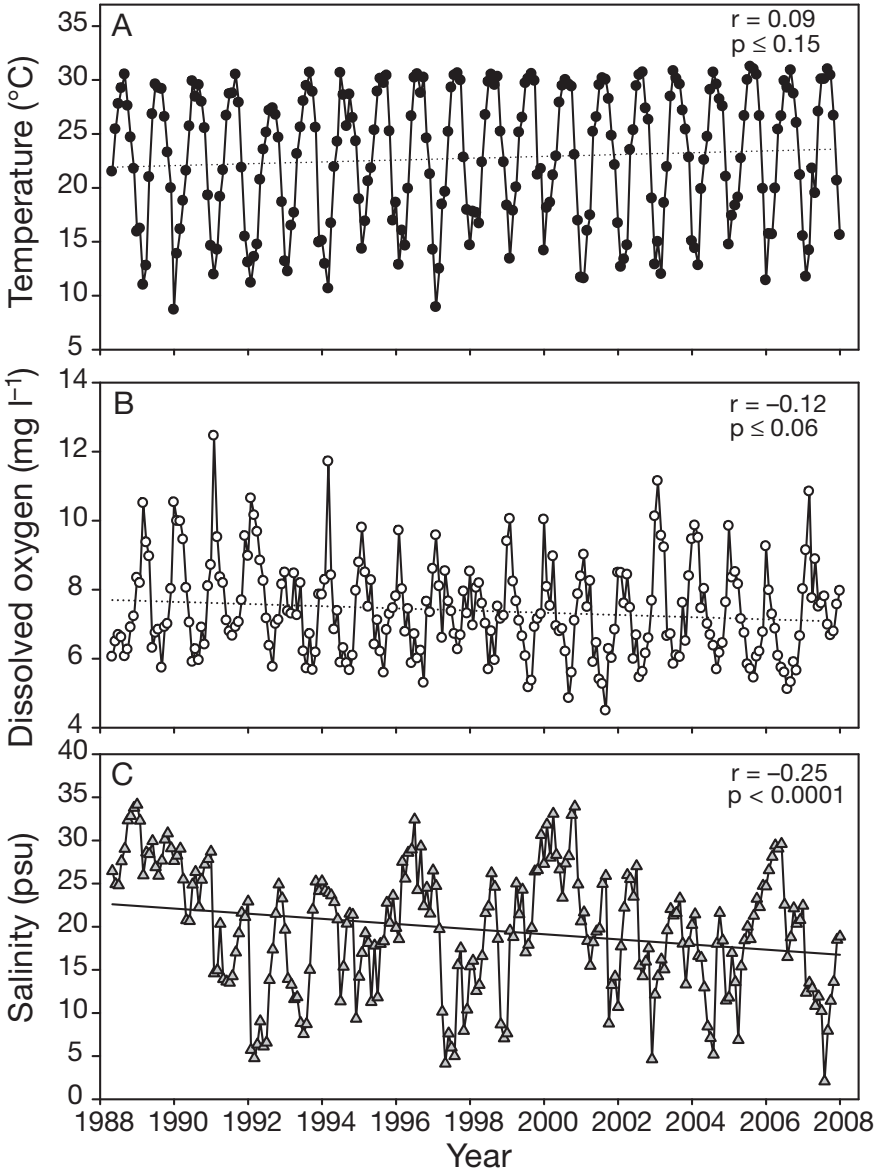

Fig. 2. Quarterly mean (A) temperature, (B) dissolved oxygen, and (C) salinity in the Lavaca-Colorado Estuary from 1988 to 2008. Significant Spearman correlations are shown as solid lines

porated into the correlations between macrobenthic and hydrological variables. This lag was created by averaging estuary-wide hydrological readings over the 3 calendar mo prior to and including the month of macrofauna sampling. Averages of hydrological variables over different time spans and lags were also briefly examined; however, the 3 mo partial lag yielded the highest correlations between salinity, temperature and dissolved oxygen and macrofaunal abundance, biomass and diversity (N1). Therefore, only the partial lag was used in this analysis. Although not reported, correlations were calculated using both quarterly and yearly means to verify that choosing the temporal extent of the means did not affect the direction and significance of the correlation. Hydrological variables were also correlated with the most abundant species and higher taxa groups found in the Lavaca-Colorado Estuary. All correlations were calculated using SAS software (SAS Institute 2009).

\section{RESULTS}

\section{Physical conditions}

Estuary-wide, temperature showed a strong seasonal signal that neither increased nor decreased over the study period $(\mathrm{r}=0.09, \mathrm{p} \leq 0.15$; Fig. $2 \mathrm{~A})$. Monthly mean temperatures ranged from $8.7^{\circ} \mathrm{C}$ to $31.2^{\circ} \mathrm{C}$, and overall mean temperatures were similar among all macrofaunal sampling stations (Table 1).

Dissolved oxygen concentrations showed a declining trend estuary-wide over the study period $(\mathrm{r}=-$ $0.12, \mathrm{p} \leq 0.06$; Fig. 2B). Dissolved oxygen also had a strong seasonal oscillation with minima in summer and maxima in winter. This trend was opposite to the seasonal temperature trend. Monthly mean dissolved oxygen concentrations ranged from $4.5 \mathrm{mg} \mathrm{l}^{-1}$ to 12.5 $\mathrm{mg} \mathrm{l}^{-1}$, and overall mean dissolved oxygen concentrations were higher at Lavaca Bay Stns A and B than at Matagorda Bay Stns C and D (Table 1).

Estuary-wide, mean salinity significantly declined during the study period $(\mathrm{r}=-0.25, \mathrm{p} \leq 0.0001$; Fig. 2C). Monthly mean salinities were highly variable, ranging from 2.1 to 34.2 , and increased spatially from Lavaca Bay Stns A and B to Matagorda Bay Stns C and D (Table 1).

Table 1. Average values for all parameters sampled quarterly (January, April, July, October) in the Lavaca-Colorado Estuary, Texas, at each of 4 stations located in 2 bays from 1988 to 2008. Lavaca Bay was dominated by freshwater inputs, while Matagorda Bay was dominated by marine inputs. $\mathrm{N}$ is number of samples, $\mathrm{n}$ is number of organisms; abundance, biomass and diversity refer to all macrofaunal organisms collected at each station

\begin{tabular}{|c|c|c|c|c|}
\hline \multirow{2}{*}{$\begin{array}{l}\text { Variable } \\
\\
\mathrm{N}\end{array}$} & \multicolumn{2}{|c|}{$\begin{array}{c}\text { Lavaca } \\
\text { Bay } \\
\text { Stn A Stn B }\end{array}$} & \multicolumn{2}{|c|}{$\begin{array}{c}\text { Matagorda } \\
\text { Bay } \\
\text { Stn C Stn D }\end{array}$} \\
\hline & 82 & 82 & 81 & 81 \\
\hline Abundance $\left(\mathrm{n} \mathrm{m}^{-2}\right)$ & 6710 & 5288 & 9836 & 16166 \\
\hline Biomass $\left(\mathrm{g} \mathrm{m}^{-2}\right)$ & 1.4 & 1.1 & 5.0 & 7.8 \\
\hline Diversity (N1 $106 \mathrm{~cm}^{-2}$ ) & 3.2 & 3.5 & 7.7 & 8.3 \\
\hline Dissolved oxygen $\left(\mathrm{mg} \mathrm{l}^{-1}\right)$ & 8.0 & 7.9 & 7.5 & 7.3 \\
\hline Salinity (psu) & 14.2 & 17.4 & 23.4 & 27.3 \\
\hline Temperature $\left({ }^{\circ} \mathrm{C}\right)$ & 21.8 & 21.8 & 22.1 & 22.1 \\
\hline $\mathrm{pH}$ & 8.1 & 8.1 & 8.1 & 8.1 \\
\hline $\mathrm{NH}_{4}\left(\mu \mathrm{mol} \mathrm{l}{ }^{-1}\right)$ & 2.3 & 3.5 & 1.6 & 1.6 \\
\hline $\mathrm{PO}_{4}\left(\mu \mathrm{mol} \mathrm{l} l^{-1}\right)$ & 1.6 & 2.8 & 0.9 & 0.8 \\
\hline $\mathrm{SiO}_{4}\left(\mu \mathrm{mol} \mathrm{l} l^{-1}\right)$ & 115.3 & 100.3 & 66.6 & 44.4 \\
\hline $\operatorname{chl} a\left(\mathrm{mg} \mathrm{l}^{-1}\right)$ & 8.2 & 8.0 & 6.9 & 7.1 \\
\hline Clay (\%) & 39.6 & 46.8 & 40.1 & 48.6 \\
\hline Silt (\%) & 25.8 & 32.7 & 24.3 & 31.1 \\
\hline Sand (\%) & 33.0 & 19.6 & 32.0 & 18.3 \\
\hline Rubble (\%) & 1.6 & 0.9 & 3.7 & 1.9 \\
\hline Depth (m) & 1.3 & 1.9 & 2.9 & 4.1 \\
\hline
\end{tabular}


Combined riverine inflow from the Lavaca, Tres Palacios and Colorado Rivers to the Lavaca-Colorado Estuary was highly variable during the study period. Combined monthly mean discharge ranged from $0.27 \mathrm{~m}^{3} \mathrm{~s}^{-1}$ to $1370 \mathrm{~m}^{3} \mathrm{~s}^{-1}$, with a mean value of $90.2 \mathrm{~m}^{3} \mathrm{~s}^{-1}$ (Fig. 3A). ONI values fluctuated from positive to negative during the study period with 2 to 4 year periodicity (Fig. 3B). NOAA classifies El Niño and La Niña events as periods with 5 consecutive mo with ONI values above or below the threshold of $\pm 0.5^{\circ} \mathrm{C}$ respectively (see NCAR). According to this classification, there were $6 \mathrm{El}$ Niño events in the study period (1991-92, 1994-95, 1997-98, 2002-03,

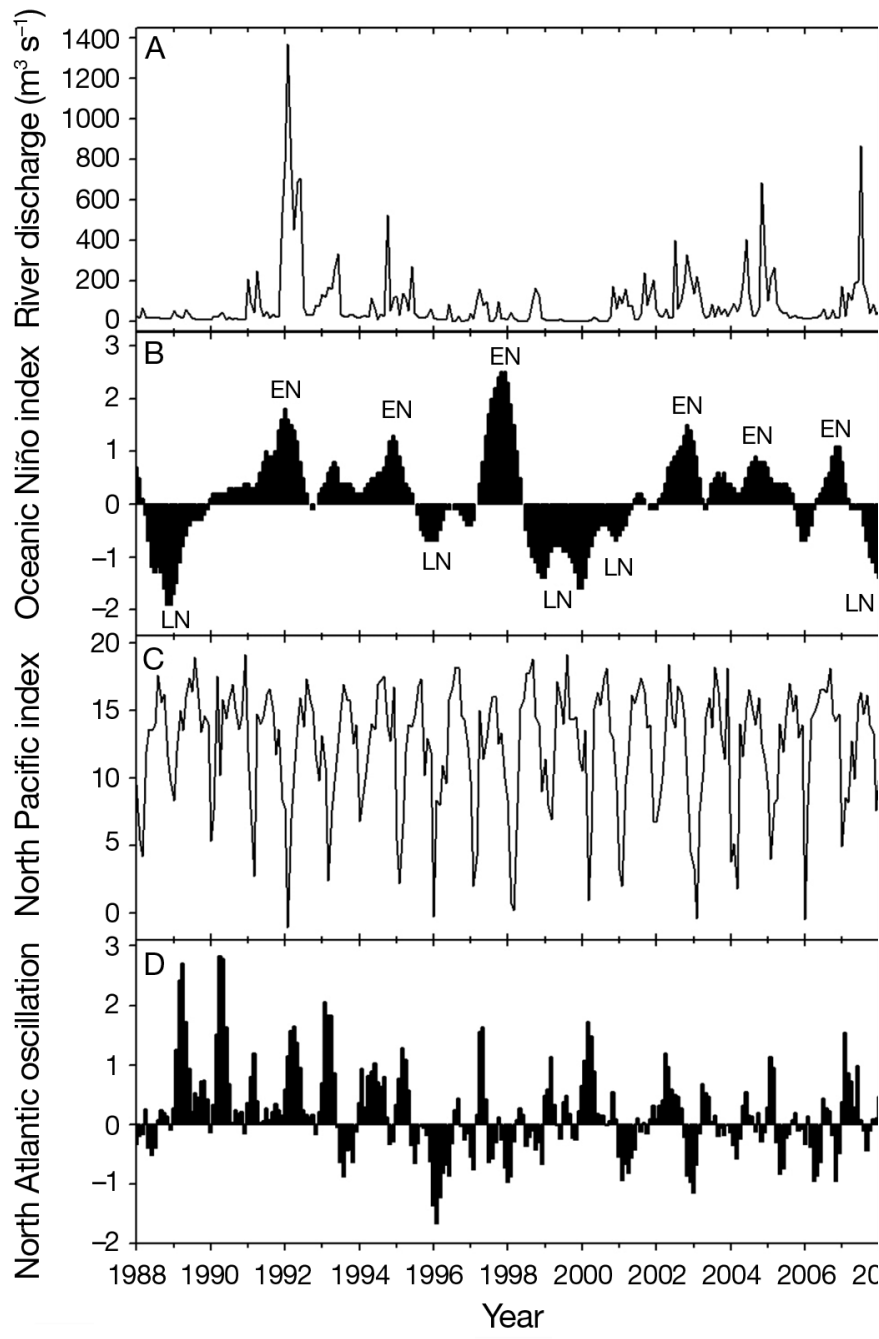

Fig. 3. (A) Quarterly mean river discharge to the LavacaColorado estuary, summed from the Lavaca, Tres Palacios and Lower Colorado Rivers from 1988 to 2008. (B) Quarterly mean Oceanic Niño Index (ONI). (C) North Pacific Index. (D) Smoothed North Atlantic Oscillation. Warm (El Niño, 'EN') and cool (La Niña, 'LN') events are defined by NOAA as periods of 5 consecutive mo above or below the ONI threshold of $\pm 0.5^{\circ} \mathrm{C}$
2004-05 and 2006-07), of which, the first and third were the strongest. The first half of the study period contained 2 whole El Niño events and the start of a third, while the second half of the study period contained 3 whole El Niño events and the end of a fourth. River discharge was significantly positively correlated with the ONI ( $\mathrm{r}=0.41, \mathrm{p}<0.0001)$ and negatively correlated with the NPI $(r=-0.24, \mathrm{p} \leq$ 0.0002). River discharge was negatively correlated with salinity $(\mathrm{r}=-0.50, \mathrm{p}<0.0001)$ and temperature $(\mathrm{r}=-0.18, \mathrm{p} \leq 0.007)$ and positively correlated with dissolved oxygen $(\mathrm{r}=0.21, \mathrm{p} \leq 0.0007)$. The ONI was also negatively correlated with salinity $(\mathrm{r}=-0.48$, $\mathrm{p}<$ $0.0001)$. The NPI was positively correlated with salinity $(\mathrm{r}=0.15, \mathrm{p} \leq 0.02)$ and temperature $(\mathrm{r}=0.74, \mathrm{p}<$ $0.0001)$ but negatively correlated with dissolved oxygen $(\mathrm{r}=-0.67, \mathrm{p}<0.0001)$. The smoothed NAO was positively correlated with dissolved oxygen $(\mathrm{r}=0.25$, $\mathrm{p} \leq 0.0001)$ and negatively correlated with temperature $(\mathrm{r}=-0.17, \mathrm{p} \leq 0.008)$.

\section{Similarities between benthic communities}

Benthic macrofaunal communities from Stns A to D were generally distinct along the spatio-salinity gradient of the study area. This was illustrated in the MDS analysis by a general salinity gradation from low (5) to salinity (35) moving from right to left across the MDS plot (Fig. 4). Overall, the communities clustered into 2 significantly different larger groups representing freshwater-dominated Lavaca Bay (right)

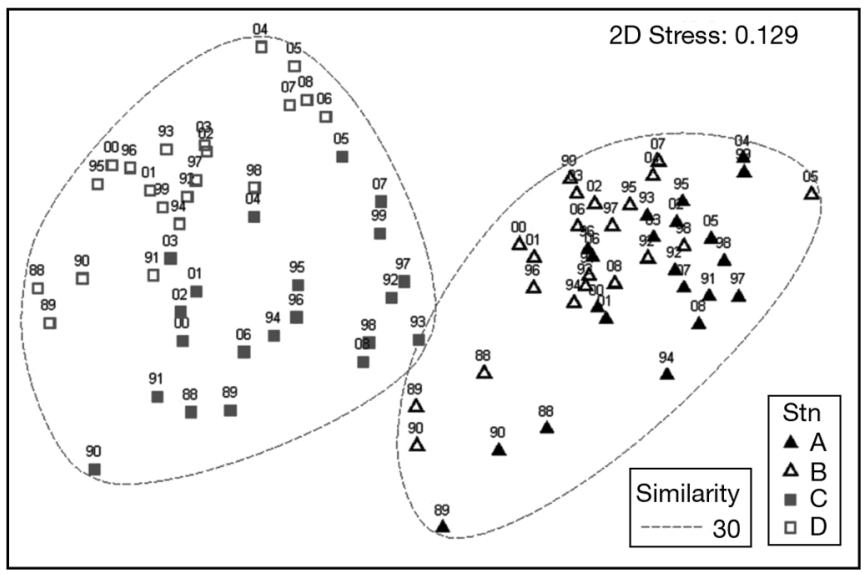

Fig. 4. Multidimensional scaling analysis of mean quarterly species-level community structure for Lavaca Bay (Stations $\mathrm{A}, \mathrm{B}$, triangles) and Matagorda Bay (Stns $\mathrm{C}, \mathrm{D}$, squares) from 1988 to 2008. Dashed lines show similarity grouping results related to differences in communities for the two bays; 30 refers to the percent similarity of samples within each group; point labels represent years 
and marine-dominated Matagorda Bay (left) with at least $30 \%$ similarity among stations in each group. The BIO-ENV procedure identified salinity as the single hydrological variable that represents the sites in a manner consistent with the macrobenthic patterns $\left(\rho_{\mathrm{w}}=0.30\right)$, the best out of any single or combination of hydrological variables measured (salinity, temperature, pH and dissolved oxygen). Further multivariate analysis using 2nd-stage MDS (Clarke et al. 2006; results not shown here) showed that temporal variability of station communities was similar within bays but very different between bays. Because of the similarity between benthic communities within each bay, the remainder of our analyses focused on the longterm trends and response of benthic macrofauna at the bay (rather than individual station) level.

\section{Long-term patterns of benthic macrofauna}

A total of 236 macrobenthic species were recorded in the Lavaca-Colorado Estuary from 1988 to 2008 (Table 2). The macrofaunal assemblage was dominated by polychaetes, with Mediomastus ambiseta being the most abundant species that represented $42 \%$ of all individuals. The 15 most abundant organisms comprised 6 polychaetes, 4 molluscs, 2 crustaceans, and 1 echinoderm. Oligochaetes and Nemerteans were also included in the 15 most abundant organisms although these 2 groups were not identified to more specific taxa groupings. These 15 organisms accounted for more than $82 \%$ of the individuals observed.

There were significant declines in benthic macrofaunal abundance, biomass and N1 diversity in Lavaca Bay and Matagorda Bay over the 20 yr study period (Fig. 5). Abundance, biomass, and N1 diversity were generally higher in Matagorda Bay than Lavaca Bay (Table 1). At the higher taxonomic level, polychaete, crustacean and mollusc abundance significantly declined in Lavaca Bay, and polychaete, mollusc, nemertean and ophiuroid abundance significantly declined in Matagorda Bay (Fig. 6, Table 3). Polychaete worms were numerically the most dominant group, constituting $83 \%$ of all organisms collected in Lavaca Bay and $68 \%$ of all organisms collected in Matagorda Bay. Of the most abundant orders, sedentary and errant polychaetes and veneroid bivalves declined significantly in both bays through time (Table 3). The most abundant species, Mediomastus ambiseta, declined significantly in both bays. Other dominant species with significant declines in abundance in Lavaca Bay were the bivalve Mulinia lateralis and the polychaete Streblospio benedicti. Polychaetes Polydora caulleryi and Minuspio cirrifera, bivalves Corbula contracta and Lepton sp. and the ophiuroid Amphiodia atra sp. all decreased in abundance over time in Matagorda Bay. Other species in both bays also had significant changes in abundance relative to time or hydrological variables; however, only the responses of the 10 most abundant species are discussed.

Table 2. Average species abundance ( $\mathrm{n} \mathrm{m}^{-2}$ ) measured at each station over all samples collected from 1988 to 2008 . Cum \%: cumulative percent, LPIL: Lowest practical identifiable level

\begin{tabular}{|c|c|c|c|c|c|c|c|c|}
\hline \multirow[t]{2}{*}{ Rank } & \multirow[t]{2}{*}{ Species name } & \multicolumn{2}{|c|}{ Lavaca Bay } & \multicolumn{2}{|c|}{ Matagorda Bay } & \multirow[t]{2}{*}{ Mean } & \multirow[t]{2}{*}{$\%$} & \multirow[t]{2}{*}{ Cum \% } \\
\hline & & Stn A & Stn B & Stn $\mathrm{C}$ & Stn D & & & \\
\hline 1 & Mediomastus ambiseta & 4042 & 3112 & 4019 & 4651 & 3956 & 41.6 & 41.6 \\
\hline 2 & Apseudes sp. A & 0 & 0 & 2 & 3756 & 940 & 9.9 & 51.5 \\
\hline 3 & Streblospio benedicti & 1045 & 833 & 367 & 187 & 608 & 6.4 & 57.9 \\
\hline 4 & Cossura delta & 50 & 285 & 547 & 465 & 337 & 3.5 & 61.5 \\
\hline 5 & Oligochaeta (LPIL) & 25 & 6 & 35 & 1217 & 321 & 3.4 & 64.9 \\
\hline 6 & Polydora caulleryi & 0 & 0 & 437 & 697 & 283 & 3 & 67.8 \\
\hline 7 & Mulinia lateralis & 370 & 249 & 437 & 21 & 269 & 2.8 & 70.7 \\
\hline 8 & Nemertea (LPIL) & 88 & 90 & 271 & 488 & 234 & 2.5 & 73.1 \\
\hline 9 & Minuspio cirrifera & 0 & 0 & 105 & 740 & 211 & 2.2 & 75.4 \\
\hline 10 & Corbula contracta & 0 & 0 & 0 & 558 & 139 & 1.5 & 76.8 \\
\hline 11 & Lepton sp. & 1 & 2 & 12 & 451 & 116 & 1.2 & 78 \\
\hline 12 & Amphiodia atra & 0 & 0 & 116 & 314 & 107 & 1.1 & 79.2 \\
\hline 13 & Periploma cf. orbiculare & 0 & 0 & 40 & 368 & 102 & 1.1 & 80.2 \\
\hline 14 & Paraprionospio pinnata & 13 & 63 & 173 & 132 & 95 & 1 & 81.3 \\
\hline \multirow[t]{3}{*}{15} & Ampelisca abdita & 288 & 56 & 18 & 8 & 92 & 1 & 82.2 \\
\hline & 221 other species & 789 & 592 & 3260 & 2114 & 1689 & 17.8 & 100 \\
\hline & Total & 6710 & 5288 & 9836 & 16166 & 9500 & 100 & \\
\hline
\end{tabular}



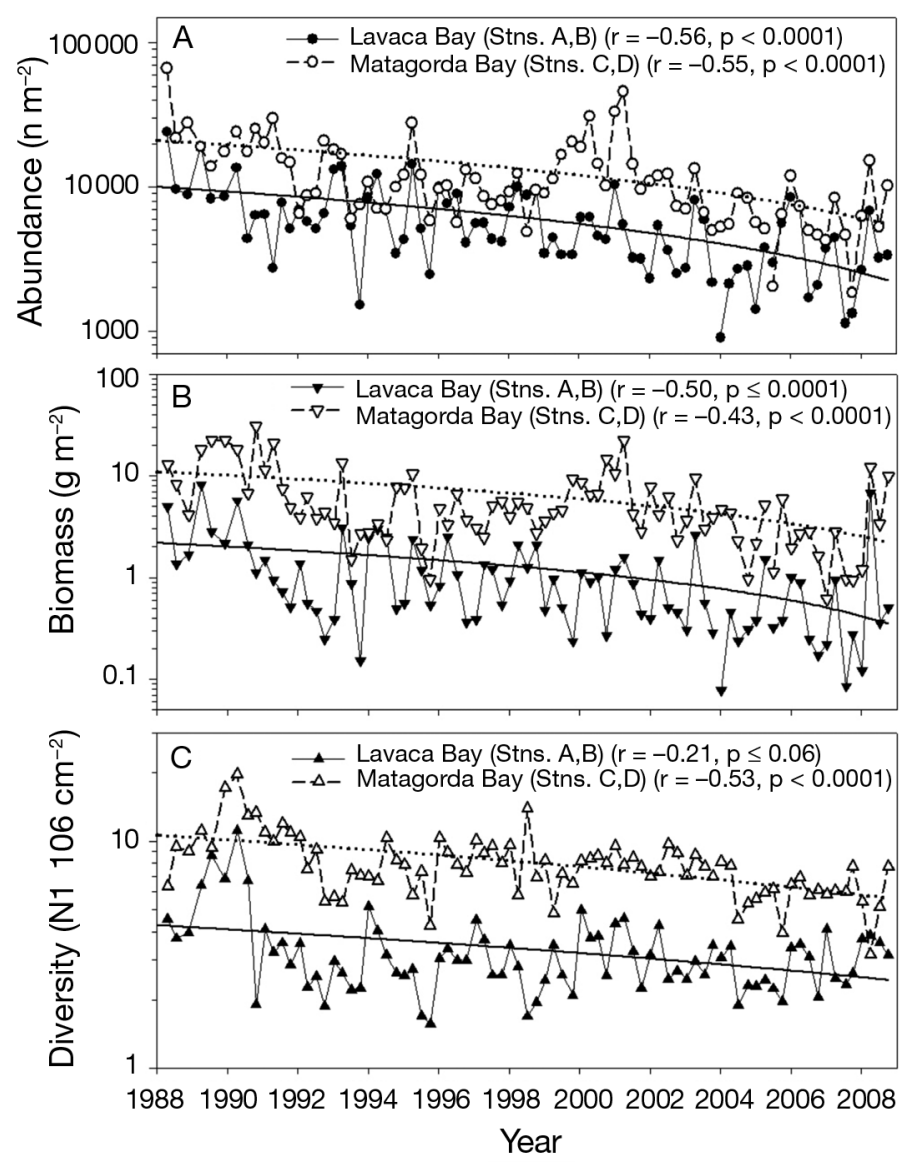

Fig. 5. Total benthic macrofauna: quarterly averages and Spearman correlations of (A) abundance, (B) biomass, and (C) N1 diversity for Lavaca Bay (Stns A,B) and Matagorda Bay (Stns C,D) from 1988 to 2008

\section{Relationships between benthic macrofauna and environmental variables}

Estuary-wide, salinity was significantly positively correlated with total biomass, abundance and N1 diversity (Figs. 7A,D,G). The ONI was negatively correlated with macrofaunal abundance $(r=-0.29, \mathrm{p} \leq$ 0.01 ) but not correlated with biomass or N1 diversity. The smoothed NAO was positively correlated with abundance $(r=0.25, p \leq 0.03)$ and biomass $(r=0.25$, $\mathrm{p} \leq 0.03)$. The NPI was not correlated with any macrofaunal descriptor. At the higher taxonomic level, polychaete, crustacean, mollusc, nemertean, ophiuroid, hemichordate and sipunculid abundance increased with increasing salinity, and chironomid larvae abundance decreased with increasing salinity (Table 4). Of the most abundant orders, sedentary polychaetes, errant polychaetes and tanaid crustaceans were positively correlated with salinity. Of the most abundant species, the polychaetes
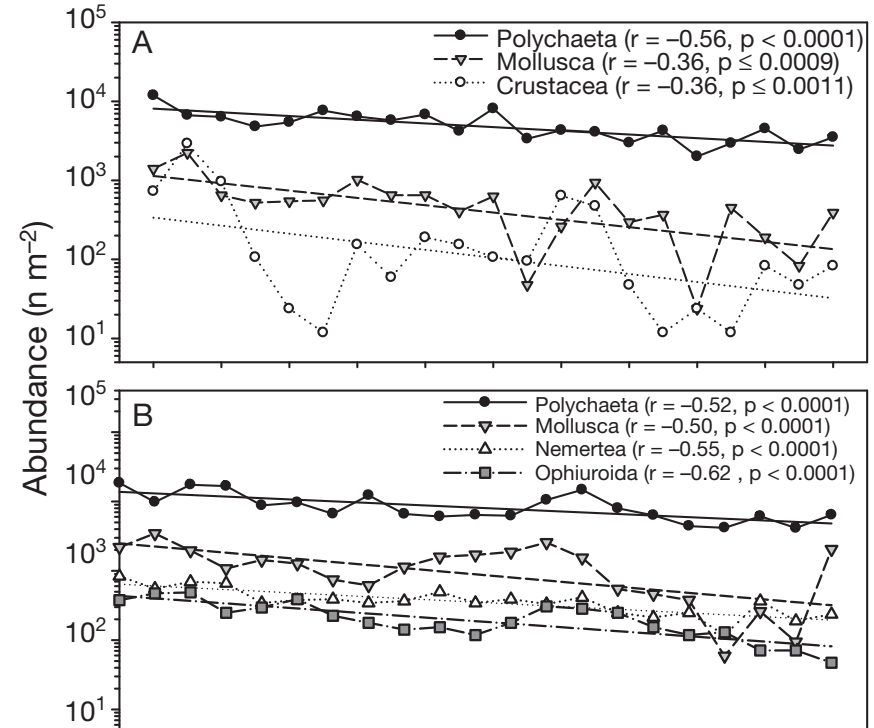

19881990199219941996199820002002200420062008 Year

Fig. 6. Annual averages and Spearman correlations of abundance for higher taxa in (A) Lavaca Bay (Stns A,B) and

(B) Matagorda Bay (Stns C,D) from 1988 to 2008

Mediomastus ambiseta and Corbula contracta, the tanaid Apseudes sp. A, and the ophiuroid Amphiodia atra all increased in abundance with increasing salinity.

Overall N1 diversity estuary-wide significantly declined with temperature (Fig. 7H). There was no significant correlation between temperature and estuary-wide abundance and biomass (Fig. 7B,E). At the higher taxa level, abundances were not significantly correlated with temperature (Table 4). Of the most abundant orders, veneroid bivalves declined in abundance with increases in temperature. Of the most abundant species, the polychaete Mediomastus ambiseta declined in abundance with increasing temperature.

Estuary-wide, there was no significant correlation between dissolved oxygen and overall abundance, biomass and N1 diversity (Fig. 7C,F,I). There were no significant correlations with dissolved oxygen at the higher taxa, order or species levels.

\section{DISCUSSION}

The existing suite of comprehensive atmospheric circulation models have painted an indeterminate picture of future climate change with some models predicting more frequent ENSO periods and others predicting less (Cane 2005, Meehl et al. 2006, Zhang 
Table 3. Spearman correlation results and abundance (no. $\mathrm{m}^{-2}$ ) of numerically dominant benthic macrofauna taxa with time for Lavaca Bay and Matagorda Bay. Only the 5 most dominant orders and 10 most dominant species are listed. Significant relationships are shown in bold. LPIL: lowest practical identifiable level

\begin{tabular}{|c|c|c|c|c|c|c|c|}
\hline \multirow[t]{2}{*}{ Taxa } & \multicolumn{3}{|c|}{$\longrightarrow$ Lavaca Bay } & \multicolumn{3}{|c|}{ Matagorda Bay -} & \multirow{2}{*}{$\begin{array}{l}\text { Estuary } \\
\text { abundance }\end{array}$} \\
\hline & $\mathrm{r}$ & $\mathrm{p}$ & Abundance & $\mathrm{r}$ & $\mathrm{p}$ & Abundance & \\
\hline \multicolumn{8}{|l|}{ Major taxa } \\
\hline Polychaeta & -0.56 & $<0.0001$ & 5051 & -0.52 & $<0.0001$ & 8821 & 6936 \\
\hline Crustacea & -0.36 & 0.0011 & 285 & -0.20 & 0.0731 & 2120 & 1202 \\
\hline Mollusca & -0.36 & 0.0009 & 553 & -0.50 & $<0.0001$ & 1237 & 895 \\
\hline Nemertea & -0.10 & 0.3723 & 86 & -0.55 & $<0.0001$ & 377 & 231 \\
\hline Ophiuroida & & & 0 & -0.62 & $<0.0001$ & 215 & 108 \\
\hline Hemichordata & & & 1 & -0.17 & 0.1276 & 114 & 57 \\
\hline Sipunculida & & & 0 & -0.19 & 0.0948 & 28 & 14 \\
\hline Chironomid larvae & -0.07 & 0.5572 & 9 & & & 0 & 4 \\
\hline \multicolumn{8}{|l|}{ Order } \\
\hline Sedentaria & -0.56 & $<0.0001$ & 4874 & -0.53 & $<0.0001$ & 7359 & 6117 \\
\hline Tanaidacea & & & 0 & -0.16 & 0.1558 & 1879 & 940 \\
\hline Veneroida & -0.31 & 0.0048 & 453 & -0.33 & 0.0024 & 540 & 497 \\
\hline Errantia & -0.44 & $<0.0001$ & 158 & -0.66 & $<0.0001$ & 827 & 493 \\
\hline Oligochaeta (LPIL) & 0.12 & 0.2722 & 15 & 0.11 & 0.3124 & 626 & 321 \\
\hline \multicolumn{8}{|l|}{ Species } \\
\hline Mediomastus ambiseta & -0.44 & $<0.0001$ & 3577 & -0.36 & 0.0010 & 4335 & 3956 \\
\hline Apseudes sp. A & & & 0 & -0.16 & 0.1558 & 1879 & 940 \\
\hline Streblospio benedicti & -0.33 & 0.0026 & 939 & 0.00 & 0.9738 & 277 & 608 \\
\hline Cossura delta & -0.20 & 0.0684 & 167 & 0.07 & 0.5362 & 506 & 337 \\
\hline Polydora caulleryi & & & 0 & -0.33 & 0.0028 & 567 & 283 \\
\hline Mulinia lateralis & -0.31 & 0.0053 & 309 & -0.09 & 0.4497 & 229 & 269 \\
\hline Minuspio cirrifera & & & 0 & -0.75 & $<0.0001$ & 423 & 211 \\
\hline Corbula contracta & & & 0 & -0.46 & $<0.0001$ & 279 & 139 \\
\hline Lepton sp. & & & 2 & -0.50 & $<0.0001$ & 231 & 116 \\
\hline Amphiodia atra & & & 0 & -0.61 & $<0.0001$ & 215 & 107 \\
\hline
\end{tabular}

et al. 2008, ). Greater consensus has been reached on the significance of increasing climate variability (Katz \& Brown 1992, Trenberth \& Hoar 1997, Hulme et al. 1999, Timmermann et al. 1999, Meehl et al. 2000). At the same time, human population growth is increasing the demand for and stress on coastal and marine resources. Regardless of average climate trends in the future, human infrastructure will likely interact with more extreme events and this will decrease stability in coastal ecosystems.

Over the past several decades the number of El Niño events has increased, which has been linked to decadal changes in climate throughout the Pacific Basin (Trenberth \& Hoar 1996). In the LavacaColorado Estuary, mean salinity significantly declined during the 20 yr study period. Observed changes in salinity were related to river discharge and the ONI because there were 2 El Niño events from 1988 to 1996 and 4 El Niño events from 1997 to 2008 (Fig. 3). Thus, the first half of the study period was drier than the second half. Similar relationships between ONI and decreasing salinity have been reported for Atlantic coast estuaries (Allen et al.
2008). Benthic macrofaunal abundance was significantly correlated with salinity and the ONI, indicating that global climate variability and the resulting effects on local salinity patterns are important factors shaping benthic macrofaunal communities.

The NAO was weakly correlated with macrofaunal abundance and biomass, although it was not significantly correlated with salinity or discharge. The positive correlation between the NAO and dissolved oxygen and negative correlation between NAO and temperature indicates that although salinity and freshwater inflow are the primary drivers of macrofauna community change, temperature and dissolved oxygen concentration, as regulated by climatic processes, also play a role in structuring macrofaunal communities. The NAO has been related to changes in temperature and/or dissolved oxygen, ultimately resulting in changes of various marine and freshwater communities including phytoplankton communities and the benthos in North America, Europe and in between (Hagberg \& Tunberg 2000, Straile \& Adrian 2000, Edwards et al. 2002, Drinkwater et al. 2003). 

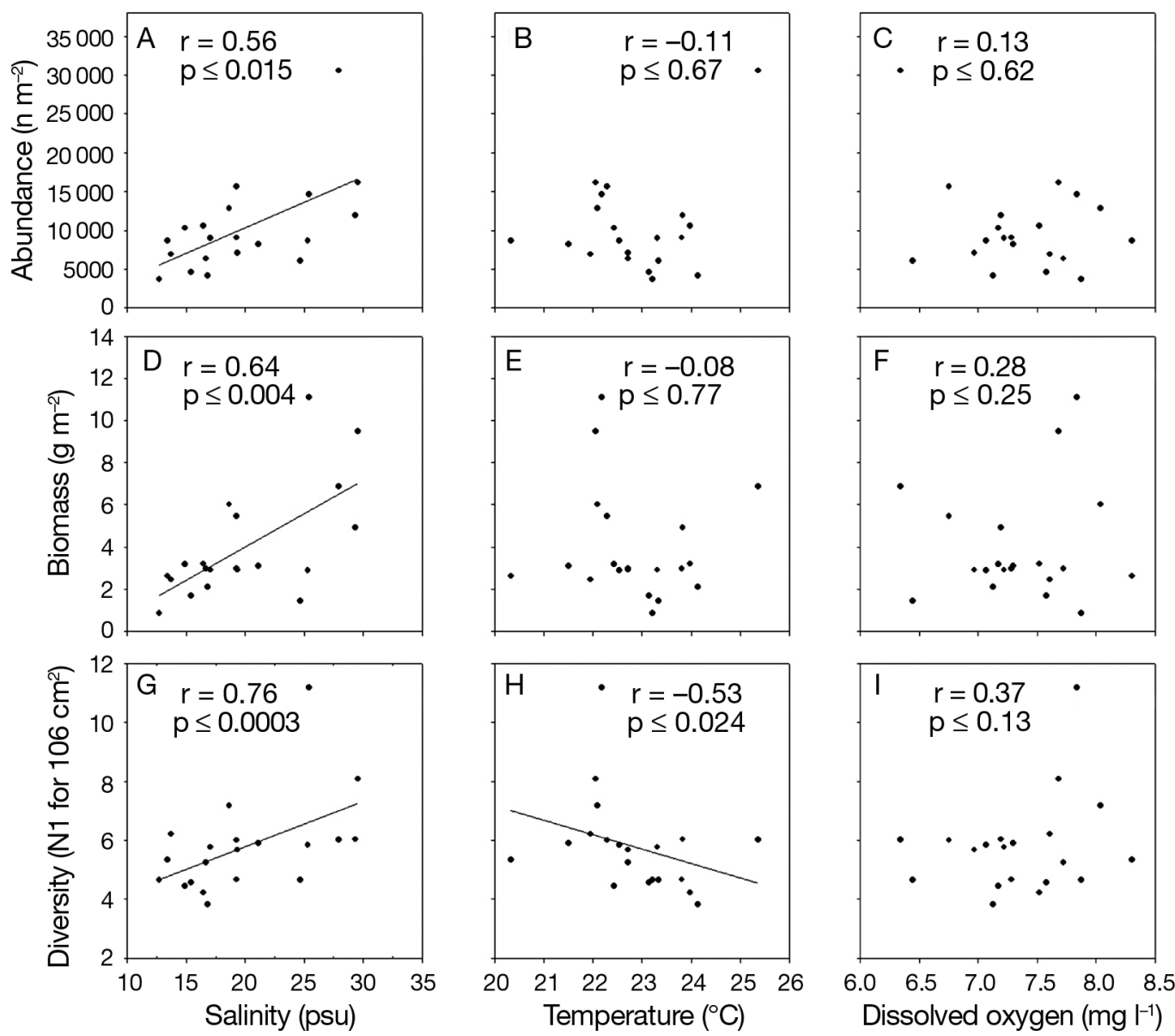

Fig. 7. Relationships of total benthic macrofaunal abundance, biomass and diversity with salinity, temperature and dissolved oxygen in the Lavaca-Colorado Estuary. Points are annual averages. Significant Spearman correlations are shown as solid lines

Climatic variability is an important factor controlling benthic variability, primarily due to bottom-up control of the population through influences on primary production (Tunberg \& Nelson 1998). The strong link between climate variables and benthic invertebrate species is also related to their salinity tolerance (Kotta et al. 2009). Although estuarine organisms are generally euryhaline, most are only found within a portion of their salinity range (Little 2000). Thus, salinity gradients play a major role in determining the abundance and distribution of estuarine organisms. The bivalve Corbula contracta and the tanaid Aspeudes sp. were only observed at the most marine-influenced Stn D in Matagorda Bay, consistent with their characterization as mid to highsalinity tolerant species (Parker 1959, Maurer et al. 1974, Daley 2002; see also National Benthic Inventory, Taxa search: www.nbi.noaa.gov/). Chironomid larvae, belonging to a freshwater/oligohaline taxonomic group, were present at very low densities only in Lavaca Bay and are generally observed during flood periods (Ritter et al. 2005). All 3 species were correlated with salinity, thus future changes in salinity gradients can be expected to alter their distribution and abundance.

Although no other influencing factors were directly analyzed in this study, the strong connection between global climate signals, precipitation, and local salinity patterns provides the most plausible mechanistic connection between climatic variation and the changing character of benthic macrofaunal communities in the estuary. In general, the marineinfluenced stations had higher values of benthic macrofaunal abundance, biomass, and diversity. Similarly, Drake et al. (2002) reported that estuarine nekton and macroinvertebrate species richness, abundance, and biomass were all positively correlated with salinity. Bioenergetic modeling of the Lavaca-Colorado Estuary has demonstrated that changes in salinity are related to changes in func- 
Table 4. Spearman partial correlations of salinity and temperature (Temp.) with major taxa and numerically dominant orders and species listed in order of decreasing abundance in the Lavaca-Colorado Estuary. There were no significant correlations with dissolved oxygen. Abbreviations as in Table 2

\begin{tabular}{|lrrrrr|}
\hline & \multicolumn{2}{c}{ Salinity } & \multicolumn{2}{c}{ Temp. } & $\begin{array}{c}\text { Abundance } \\
\text { (no. } \mathrm{m}^{-2} \text { ) }\end{array}$ \\
& $\mathrm{r}$ & $\mathrm{p}$ & $\mathrm{r}$ & $\mathrm{p}$ & \\
Major taxa & & & & & \\
Polychaeta & $\mathbf{0 . 3 6}$ & $\mathbf{0 . 0 0 1 3}$ & -0.18 & 0.1218 & 6936 \\
Crustacea & $\mathbf{0 . 4 1}$ & $\mathbf{0 . 0 0 0 3}$ & -0.17 & 0.1443 & 1202 \\
Mollusca & $\mathbf{0 . 4 3}$ & $\mathbf{0 . 0 0 0 1}$ & -0.22 & 0.0618 & 895 \\
Nemertea & $\mathbf{0 . 2 7}$ & $\mathbf{0 . 0 1 8 4}$ & -0.03 & 0.7770 & 231 \\
Ophiuroida & $\mathbf{0 . 3 3}$ & $\mathbf{0 . 0 0 3 5}$ & -0.12 & 0.2853 & 108 \\
Hemichordata & $\mathbf{0 . 2 8}$ & $\mathbf{0 . 0 1 3 4}$ & -0.03 & 0.8072 & 57 \\
Sipunculida & $\mathbf{0 . 2 6}$ & $\mathbf{0 . 0 2 3 0}$ & 0.02 & 0.8387 & 14 \\
Chironomid larvae & $\mathbf{- 0 . 3 6}$ & $\mathbf{0 . 0 0 1 4}$ & 0.13 & 0.2545 & 4 \\
Order & & & & & \\
Sedentaria & $\mathbf{0 . 3 6}$ & $\mathbf{0 . 0 0 1 7}$ & -0.17 & 0.1355 & 6117 \\
Tanaidacea & $\mathbf{0 . 2 5}$ & $\mathbf{0 . 0 2 9 1}$ & -0.10 & 0.3963 & 940 \\
Veneroida & 0.13 & 0.2516 & $-\mathbf{0 . 3 4}$ & $\mathbf{0 . 0 0 3 3}$ & 497 \\
Errantia & $\mathbf{0 . 4 6}$ & $\mathbf{0 . 0 0 0 1}$ & -0.11 & 0.3356 & 493 \\
Oligochaeta (LPIL) & -0.09 & 0.4489 & -0.16 & 0.1676 & 321 \\
Species & & & & & \\
Mediomastus ambiseta & $\mathbf{0 . 3 3}$ & $\mathbf{0 . 0 0 3 7}$ & $\mathbf{- 0 . 2 4}$ & $\mathbf{0 . 0 3 7 3}$ & 3956 \\
Apseudes sp. A & $\mathbf{0 . 2 5}$ & $\mathbf{0 . 0 2 9 1}$ & -0.10 & 0.3963 & 940 \\
Streblospio benedicti & 0.00 & 0.9765 & 0.11 & 0.3519 & 608 \\
Cossura delta & 0.07 & 0.5609 & -0.10 & 0.4169 & 337 \\
Polydora caulleryi & $\mathbf{0 . 3 2}$ & $\mathbf{0 . 0 0 4 6}$ & -0.05 & 0.6441 & 283 \\
Mulinia lateralis & 0.13 & 0.2723 & -0.19 & 0.1030 & 269 \\
Minuspio cirrifera & 0.19 & 0.1043 & -0.08 & 0.4863 & 211 \\
Corbula contracta & $\mathbf{0 . 4 4}$ & $\mathbf{0 . 0 0 0 1}$ & 0.00 & 0.9741 & 139 \\
Lepton sp. & 0.08 & 0.5055 & -0.15 & 0.2035 & 116 \\
Amphiodia atra & $\mathbf{0 . 3 2}$ & $\mathbf{0 . 0 0 5 8}$ & -0.12 & 0.3212 & 107 \\
\hline
\end{tabular}

2002). The dominance of the polychaetes Mediomastus ambiseta, Cossura delta, and Streblospio benedicti and the bivalve Mulinia lateralis throughout the estuary suggests cycles of disturbance and stability. Both $M$. ambiseta and $S$. benedicti have wide tolerance ranges for changes in salinity, such that when other species are stressed or killed by hypersaline conditions, both can survive and dominate. $S$. benedicti, $C$. delta and $M$. lateralis proliferate rapidly after significant disturbances, while $M$. ambiseta generally dominates after conditions stabilize (Grassle \& Grassle 1974, Santos \& Simon 1980, Rakocinski et al. 2000, Palmer et al. 2002, Ritter et al. 2005). Polydora caulleryi, a dominant polychaete species in Matagorda Bay, is also an indicator of later successional stages post-disturbance (Palmer et al. 2002). The overall dominance of $M$. ambiseta, an equilibrium species, at all stations in both bays implies that the system is generally stable or returns to stability relatively quickly post-disturbance. Similarly, in the St. Lucia Estuary in southern Africa, a tional ecology, with increases in salinity (and concordant decreases in nutrient concentrations) translated into increased biomass of deposit feeders and decreased biomass of suspension feeders (Kim \& Montagna 2009). Because benthic macrofauna provide a necessary food source for many aquatic and terrestrial species, fluctuations in their abundance can influence recruitment patterns in coastal fishes and avian migratory behavior (Schneider \& Harrington 1981, Hines et al. 1997, Tunberg \& Nelson 1998).

Warmer temperatures driven by future increases in greenhouse gas levels may increase global precipitation intensity through increased evaporation, resulting in a more dynamic hydrologic cycle (Emanuel 2005, Wentz et al. 2007). If the frequency of strong El Niño/La Niña periods increases, the frequency and severity of floods and droughts may also increase (Timmermann et al. 1999). An increasingly unstable climate will challenge the resistance and resilience of ecosystems and may lead to potentially serious effects. Floods can be classified as disturbance events in estuaries because rapid changes in salinity can affect benthic communities (Montagna et al. core group of macrobenthic taxa persists during prolonged hypersalinity, serving to maintain ecosystem function under high levels of environmental variability (MacKay et al. 2010). Although these benthic communities have proven resilient to past disturbances, future degradation of these habitats due to coastal and water resource development may increase their vulnerability to climate variability and disturbance events.

There was no significant linear trend in temperature during the 20 yr study period. Significant longterm increases in winter water temperatures have been reported for East Coast USA estuaries (Nixon et al. 2004, Allen et al. 2008) but were not observed for the Lavaca-Colorado Estuary. The overall average rate of increase in water temperature from 1976 to 2007 along the entire Texas coast has been $0.0428^{\circ} \mathrm{C}$ $\mathrm{yr}^{-1}$, which translates into an increase of $1^{\circ} \mathrm{C}$ in $23 \mathrm{yr}$ (Montagna et al. 2011). The coast-wide rate of water temperature increase is similar to a coast-wide rate of increase in air temperature since 1980 (NielsenGammon 2011). The lack of a significant trend in temperature during this study period is likely due to 
the 4 El Niño events from 1997 to 2008 and winter temperatures in Texas estuaries that have been generally mild since 1993, which has affected overwintering of fish populations (Tolan \& Fisher 2009). The negative relationships between individual taxa and temperature observed in the current study may be due to seasonality. Shallow-water macrobenthic communities often show seasonal patterns of abundance, recruitment, and mortality with higher benthic abundance during the cooler months when nektonic and epibenthic predators are less abundant (Boesch et al. 1976, Whaley \& Minello 2002, Beseres \& Feller 2007). Although no long-term increases in temperature were observed over the $20 \mathrm{yr}$ study period, global mean temperatures are expected to rise over the next century (Watson et al. 1996), and temperatures have risen in Texas estuaries in general (Montagna et al. 2011). Future warming may lead to more frequent El Niño periods (Timmermann et al. 1999), thus temperature may play a larger role (than currently) in shaping estuarine benthic abundance and community structure (Hiscock et al. 2004).

Understanding the relationship between estuarine condition and estuarine resources is critical for addressing water management questions, particularly in light of increasing climate variability. While drivers other than physical hydrological factors can obviously also affect macrofauna communities, the strong links between macrofauna community characteristics, salinity, and climate variability indicate that benthic macrofaunal dynamics in the LavacaColorado Estuary are noticeably affected by climatic conditions. Future shifts in climatic conditions may have strong impacts on species diversity, abundance, community structure and distribution. In the future, for a given amount of precipitation, water demand and evaporation in Texas will increase and water supply will decrease (Nielsen-Gammon 2011). The resulting increased demands and stresses on aquatic systems will likely have significant effects on benthic macrofaunal populations and the associated trophic linkages.

By conducting in situ monitoring and research, scientists can better determine the ecological and socioeconomic impacts of climate variability. This includes predicting changes in macrofaunal communities and resulting impacts on nutrient cycling and secondary production of higher trophic levels if inflow volumes are changed. Information on the mechanisms by which natural and anthropogenic disturbances affect estuarine species can help managers plan and adapt water resource management strategies to ensure long-term maintenance of estuarine resources.
Acknowledgements. We thank R. Kalke and other support workers who implemented most of the benthic field and laboratory work for this project. The field work for this study was supported by a grant from the Texas Water Development Board, Research and Planning Fund, Research Grants, authorized under the Texas Water Code, Chapter 15, and as provided in $\S 16.058$ and $\S 11.1491$, and a contract from the Lower Colorado River Authority PO no. 49032. Much of the analytical work was supported by grant no. NA09NMF4720179 from the National Oceanic and Atmospheric Administration under the Comparative Assessment of Marine Ecosystem (CAMEO) program.

\section{LITERATURE CITED}

Alber M (2002) A conceptual model of estuarine freshwater inflow management. Estuaries 25:1246-1261

Allen DM, Ogburn-Matthews V, Buck T, Smith EM (2008) Mesozooplankton responses to climate change and variability in a southeastern US estuary (1981-2003). J Coast Res Spec Issue 55:95-110

Arismendez SS (2010) Land-water nutrient coupling processes in central Texas estuaries. $\mathrm{PhD}$ dissertation, Texas A\&M University-Corpus Christi, TX

Bates BC, Kundzewicz ZW, Wu S, Palutikof JP (eds) (2008) Climate change and water. Technical Paper of the Intergovernmental Panel on Climate Change, IPCC Secretariat, Geneva

Beseres JJ, Feller RJ (2007) Importance of predation by white shrimp Litopenaeus setiferus on estuarine subtidal macrobenthos. J Exp Mar Biol Ecol 344:193-205

> Beseres Pollack J, Kinsey JW, Montagna PA (2009) Freshwater Inflow Biotic Index (FIBI) for the Lavaca-Colorado Estuary, Texas. Environ Bioindic 4:153-169

- Bilyard GR (1987) The value of benthic infauna in marine pollution monitoring studies. Mar Pollut Bull 18:581-585

Boesch DF, Wass ML, Virnstein RW (1976) The dynamics of estuarine benthic communities. In: Wiley ML (ed) Estuarine processes, Vol 1. Academic Press, New York, NY, p 177-196

- Cane MA (2005) The evolution of El Niño, past and future. Earth Planet Sci Lett 230:227-240

Clarke KR (1993) Non-parametric multivariate analyses of changes in community structure. Aust J Ecol 18:117-143

Clarke KR, Ainsworth M (1993) A method of linking multivariate community structure to environmental variables. Mar Ecol Prog Ser 92:205-219

Clarke KR, Gorley RN (2006) PRIMER v6: user manual/tutorial. PRIMER-E, Plymouth

Clarke KR, Somerfield PJ, Airoldi L, Warwick RM (2006) Exploring interactions by second-stage community analyses. J Exp Mar Biol Ecol 338:179-192

Daley GM (2002) Creating a paleoecological framework for evolutionary and paleoecological studies: an example from the Fort Thompson Formation (Pleistocene) of Florida. Palaios 17:419-434

> Drake P, Arias AM, Baldó F, Cuesta JA and others (2002) Spatial and temporal variation of the nekton and hyperbenthos from a temperate European estuary with regulated freshwater inflow. Estuaries 25:451-468

Drinkwater KF, Belgrano A, Borja A, Conversi A and others (2003) The response of marine ecosystems to climate variability associated with the North Atlantic Oscillation. In: Hurrell JW, Kushnir Y, Ottersen G, Visbeck M (eds) 
The North Atlantic Oscillation: climatic significance and environmental impact, Geophysical Monograph Vol 134. American Geophysical Union, Washington, DC, p 211-234

Edwards M, Beaugrand G, Reid PC, Rowden AA, Jones MB (2002) Ocean climate anomalies and the ecology of the North Sea. Mar Ecol Prog Ser 239:1-10

Ellis MJ, Coull BC (1989) Fish predation on meiobenthos: field experiments with juvenile spot Leiostomus xanthurus Lacépède. J Exp Mar Biol Ecol 130:19-32

Emanuel K (2005) Increasing destructiveness of tropical cyclones over the past 30 years. Nature 436:686-688

Friedman TL (2010) Global weirding is here. New York Times, February 17, p A23

> Gershunov A, Barnett TP (1998) ENSO influence on intraseasonal extreme rainfall and temperature frequencies in the contiguous United States: observations and model results. J Clim 11:1575-1586

Grassle JF, Grassle JP (1974) Opportunistic life histories and genetic systems in marine benthic polychaetes. J Mar Res 32:253-284

> Hagberg J, Tunberg BG (2000) Studies on the covariation between physical factors and the long-term variation of the marine soft bottom macrofauna in western Sweden. Estuar Coast Shelf Sci 50:373-385

Hill MO (1973) Diversity and evenness: a unifying notation and its consequences. Ecology 54:427-432

> Hines AH, Whitlatch RB, Thrush SF, Hewitt JE, Cummings VJ, Dayton PK, Legendre P (1997) Nonlinear foraging response of a large marine predator to benthic prey: eagle ray pits and bivalves in a New Zealand sandflat. J Exp Mar Biol Ecol 216:191-210

> Hiscock K, Southward A, Tittley I, Hawkins S (2004) Effects of changing temperature on benthic marine life in Britain and Ireland. Aquat Conserv 14:333-362

> Hulme M, Barrow EM, Arnell NW, Harrison PA, Johns TC, Downing TE (1999) Relative impacts of human-induced climate change and natural climate variability. Nature 397:688-691

> Hurrell JW, Deser C (2009) North Atlantic climate variability: the role of the North Atlantic Oscillation. J Mar Syst 78:28-41

Hurrell JW, Kushnir Y, Ottersen G, Visbeck M (eds) (2003) An overview of the North Atlantic Oscillation. In: The North Atlantic Oscillation: climatic significance and environmental impact, Geophysical Monograph, Vol 134. American Geophysical Union, Washington, DC, p 1-35

Katz RW, Brown BG (1992) Extreme events in a changing climate: variability is more important than averages. Clim Change 21:289-302

Kim HC, Montagna PA (2009) Implications of Colorado river (Texas, USA) freshwater inflow to benthic ecosystem dynamics: a modeling study. Estuar Coast Shelf Sci 83: 491-504

Kotta J, Kotta I, Simm M, Põllupüü M (2009) Separate and interactive effects of eutrophication and climate variables on the ecosystem elements of the Gulf of Riga. Estuar Coast Shelf Sci 84:509-518

Little C (2000) The biology of soft shores and estuaries. The biology of habitats series. Oxford University Press, Oxford

Ludwig JA, Reynolds JF (1988) Statistical ecology: a primer on methods and computing, Vol 1. John Wiley \& Sons, New York
MacKay F, Cyrus D, Russell KL (2010) Macrobenthic invertebrate responses to prolonged drought in South Africa's largest estuarine lake complex. Estuar Coast Shelf Sci 86: 553-567

> Mansour RA, Lipcius RN (1991) Density-dependent foraging and mutual interference in blue crabs preying upon infaunal clams. Mar Ecol Prog Ser 72:239-246

Maurer D, Watling L, Aprill G (1974) The distribution and ecology of common marine and estuarine pelecypods in the Delaware Bay area. Nautilus 88:38-45

Meehl GA, Zwiers F, Evans J, Knutson T, Mearns L, Whetton P (2000) Trends in extreme weather and climate events: issues related to modeling extremes in projections of future climate change. Bull Am Meteorol Soc 81:427-436

> Meehl GA, Teng HY, Branstator G (2006) Future changes of El Niño in two global coupled climate models. Clim Dyn 26:549-566

> Montagna PA, Kalke RD, Ritter C (2002) Effect of restored freshwater inflow on macrofauna and meiofauna in upper Rincon Bayou, Texas, USA. Estuaries 25: 1436-1447

Montagna PA, Palmer TA, Kalke RD, Gossmann A (2008) Suitability of using a limited number of sampling stations to represent benthic habitats in Lavaca-Colorado Estuary, Texas. Environ Bioindic 3:156-171

Montagna PA, Brenner J, Gibeaut J, Morehead S (2011) Coastal impacts. In: Schmandt J, North GR, Clarkson J (eds) The impact of global warming on Texas, 2nd edn. University of Texas Press, Austin, TX, p 96-123

Nielsen-Gammon JW (2011) The changing climate of Texas. In: Schmandt J, North GR, Clarkson J (eds) The impact of global warming on Texas, 2nd edn. University of Texas Press, Austin, TX, p 39-68

Nixon SX, Granger S, Buckley BA, Lamont M, Rowell B (2004) A one hundred and seventeen year coastal water temperature record from Woods Hole, Massachusetts. Estuaries 27:397-404

NOAA (National Oceanic and Atmospheric Administration) (2009) Impacts of El Niño and benefits of El Niño prediction. Tropical Atmosphere Ocean Project. Available at www.pmel.noaa.gov/tao/elnino/impacts.html

Orlando SPJ, Rozas LP, Ward GH, Klein CJ (1993) Salinity characteristics of Gulf of Mexico estuaries. Strategic Environmental Assessments Division, Office of Ocean Resources Conservation and Assessment, National Oceanic and Atmospheric Administration, Silver Spring, MD

> Palmer TA, Montagna PA, Kalke RD (2002) Downstream effects of restored freshwater inflow to Rincon Bayou, Nueces Delta, Texas, USA. Estuaries 25:1448-1456

Parker RH (1959) Macro-invertebrate assemblages of central Texas coastal bays and Laguna Madre. Am Assoc Pet Geol Bull 43:2100-2166

Pearson TH, Rosenberg R (1978) Macrobenthic succession in relation to organic enrichment and pollution of the marine environment. Oceanogr Mar Biol Annu Rev 16: 229-311

Peirson WL, Bishop K, Van Senden D, Horton PR, Adamantidis CA (2002) Environmental water requirements to maintain estuarine processes. Environmental flows initiative technical report no. 3. Commonwealth of Australia, Canberra

Rakocinski CF, Brown SS, Gaston GR, Heard RW, Walker WW, Summers JK (2000) Species-abundance-biomass responses by estuarine macrobenthos to sediment chem- 
ical contamination. J Aquat Ecosyst Stress Recovery 7: 201-214

Ritter C, Montagna PA, Applebaum S (2005) Short-term succession dynamics of macrobenthos in a salinity-stressed estuary. J Exp Mar Biol Ecol 323:57-69

Ropelewski CF, Halpert MS (1986) North American precipitation and temperature patterns associated with the El Niño/Southern Oscillation (ENSO). Mon Weather Rev 114:2352-2362

Sager DR (2002) Long-term variation in mercury concentrations in estuarine organisms with changes in releases into Lavaca Bay, Texas. Mar Pollut Bull 44:807-815

Santos SL, Simon JL (1980) Response of soft-bottom benthos to annual catastrophic disturbance in a south Florida estuary. Mar Ecol Prog Ser 3:347-355

SAS Institute (2009) Base SAS $® 9.2$ procedures guide: statistical procedures, 2nd edn. SAS Institute, Cary, NC

Scavia D, Field JC, Boesch DF, Buddemeier RW and others (2002) Climate change impacts on US coastal and marine ecosystems. Estuaries 25:149-164

Schlacher TA, Wooldridge TH (1996) Ecological responses to reductions in freshwater supply and quality in South Africa's estuaries: lessons for management and conservation. J Coast Conserv 2:115-130

Schmidt N, Luther ME (2002) ENSO impacts on salinity in Tampa Bay, Florida. Estuaries 25:976-984

Schneider DC, Harrington BA (1981) Timing of shorebird migration in relation to prey depletion. Auk 98:801-811

Straile D, Adrian R (2000) The North Atlantic Oscillation and plankton dynamics in two European lakes - two variations on a general theme. Glob Change Biol 6:663-670

TCRPP (Texas Clean Rivers Program Partners) (2007) 2007 basin summary report: a summary of water quality in the Colorado River Basin from 2002-2006. Available at www. lcra.org/library/media/public/docs/crp/crpBSR2007.pdf

Timmermann A, Oberhuber J, Bacher A, Esch M, Latif M, Roeckner E (1999) Increased El Niño frequency in a climate model forced by future greenhouse warming. Nature 398:694-697

Tolan JM (2007) El Niño-Southern Oscillation impacts translated to the watershed scale: estuarine salinity patterns along the Texas Gulf Coast, 1982 to 2004. Estuar Coast Shelf Sci 72:247-260

Tolan JM, Fisher M (2009) Biological response to changes in climate patterns: population increases of gray snapper (Lutjanus griseus) in Texas bays and estuaries. Fish Bull 107:36-44

Trenberth KE, Hoar TJ (1996) The 1990-1995 El NiñoSouthern Oscillation event: longest on record. Geophys

Editorial responsibility: Jana Davis, Annapolis, Maryland, USA
Res Lett 23:57-60

> Trenberth KE, Hoar TJ (1997) El Niño and climate change. Geophys Res Lett 24:3057-3060

- Trenberth KE, Hurrell JW (1994) Decadal atmosphereocean variations in the Pacific. Clim Dyn 9:303-319

Tunberg BG, Nelson WG (1998) Do climatic oscillations influence cyclical patterns of soft bottom macrobenthic communities on the Swedish west coast? Mar Ecol Prog Ser 170:85-94

USEPA (United States Environmental Protection Agency) (2011) Alcoa/Lavaca Bay, Calhoun County, Texas. US EPA ID no. TXD008123168, Site ID: 0601752. US Environmental Protection Agency, Dallas, TX

Vörösmarty CJ, Green P, Salisbury J, Lammers RB (2000) Global water resources: vulnerability from climate change and population growth. Science 289:284-288

Ward GH Jr, Armstrong NE (1980) Matagorda Bay, Texas, its hydrography, ecology, and fishery resources. Report FWS/OB5-81/52, US Fish and Wildlife Service, US Department of the Interior, Washington, DC

Watson RT, Zinyowera MC, Moss RH (1996) Climate change 1995: impacts, adaptations, and mitigation of climate change: scientific-technical analyses. Contribution of working group II to the second assessment report of the Intergovernmental Panel on Climate Change. Cambridge University Press, New York, NY

Weisberg SB, Ranasinghe JA, Dauer DM, Schaffner LC, Diaz RJ, Frithsen JB (1997) An estuarine benthic index of biotic integrity (B-IBI) for the Chesapeake Bay. Estuaries 20:149-158

> Wentz FJ, Ricciardulli L, Hilburn K, Mears C (2007) How much more rain will global warming bring? Science 317 : 233-235

Whaley SD, Minello TJ (2002) The distribution of benthic infauna of a Texas salt marsh in relation to the marsh edge. Wetlands 22:753-766

Whitfield AK, Adams JB, Bate GC, Bezuidenhout K and others (2008) A multidisciplinary study of a small, temporarily open/closed South African estuary, with particular emphasis on the influence of mouth state on the ecology of the system. Afr J Mar Sci 30:453-473

Wilber DH, Bass R (1998) Effect of the Colorado River diversion on Matagorda Bay epifauna. Estuar Coast Shelf Sci 47:309-318

Wolanski E (2007) Estuarine ecohydrology. Elsevier, Amsterdam

> Zhang Q, Guan Y, Yang HJ (2008) ENSO amplitude change in observation and coupled models. Adv Atmos Sci 25: 361-366

Submitted: March 16, 2010; Accepted: June 20, 2011

Proofs received from author(s): August 24, 2011 